\title{
The Impact of Regulating Bluefin Tuna Exports on the Japanese Tuna Market
}

\author{
Takashi Ishida ${ }^{1}$ \\ ${ }^{1}$ Graduate School of Horticulture, Chiba University, Chiba, Japan \\ Correspondence: Takashi Ishida, School of Management, Northern Canada University, Toronto Graduate School \\ of Horticulture, Chiba University 648, Matsudo Matsudo-city, Chiba, Japan. Tel: 81-47-308-8932. E-mail: \\ t.ishida@chiba-u.jp
}

Received: March 11, $2015 \quad$ Accepted: May 21, $2015 \quad$ Online Published: June 12, 2015
doi:10.5539/jfr.v4n4p103
URL: http://dx.doi.org/10.5539/jfr.v4n4p103

\begin{abstract}
In order to understand the impact of regulating bluefin tuna exports on the Japanese tuna market, we have to clarify the inter-species price relationship. This article investigates the market linkages among four tuna species, bluefin tuna, albacore tuna, bigeye tuna and yellowfin tuna, in Japan. Vector autoregressive distributed lag (VARDL) model is used to simulate the impact of a decrease in the bluefin tuna supply on the price of bluefin tuna and other species. The result is that regulating bluefin tuna exports raise only the price of bluefin tuna but have little impact on the prices of other tuna species.
\end{abstract}

Keywords: market linkage, tuna, VARDL model

\section{Introduction}

In recent decades, the tuna catch has been increasing, year by year. Figure 1 shows the shift in the world's gross tuna catches from 1950 to 2009. From this figure, we can see that the tuna catch increased from below 500,000 tons in the 1950 s to 2 million tons in the 2000s. With the increase in the tuna catch, tuna populations continue to decrease and the existence of bluefin tuna in particular is on the line. In order to maintain the tuna population, international management organizations of tuna stocks are strengthening fishery regulations. At the meeting of the Washington Convention in March 2010, a resolution calling for the prohibitions on the import and export of Mediterranean and Atlantic bluefin tuna was introduced. The meeting voted to reject the resolution in the end. However, the discussion of export regulations is likely to continue because there is no hope that the tuna population will ever recover.

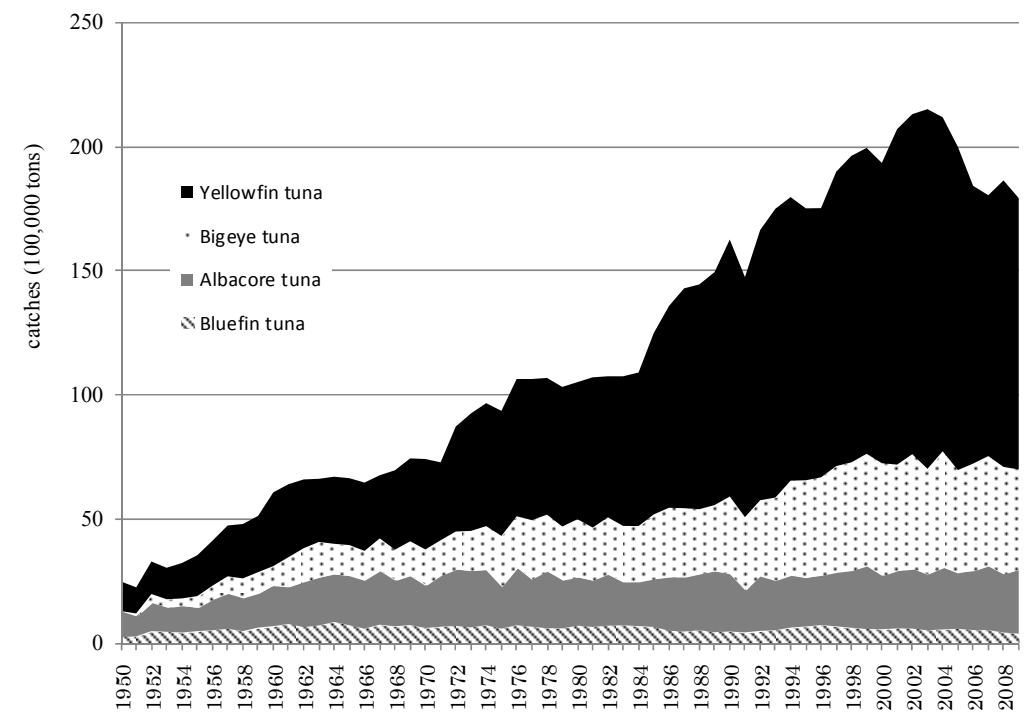

Figure 1. Trends in the world's gross tuna catches (FAO Global production statistics 1950-2009) 
The regulation of bluefin tuna export will have impacts on tuna markets. Predicting the impact of the export regulations on the tuna market will contribute to considering inventory control or supply planning. As Japan is the world's largest consumer of tuna, accounting for a quarter of the world's tuna catches, the export regulations will have major impacts on the tuna market in Japan. This study analyzes the impact of export regulations on the tuna market in Japan. Because Japan is the largest consumer of tuna, changes in the Japanese tuna market will affect the markets in other tuna consuming countries. This indicates that estimating the impact of regulating bluefin tuna exports on the Japanese tuna market will be useful for other tuna consuming countries.

There are four species of tuna eaten widely in Japan: bluefin tuna, albacore tuna, bigeye tuna and yellowfin tuna. The regulation of bluefin tuna exports might raise not only the price of bluefin tuna but the prices of other types of tuna. Table 1 shows the average monthly supply and the average price of these species of tuna from 2000 to 2009. A glance at Table 1 reveals that supply and price vary significantly among species. The species with the greatest amount of supply is bigeye tuna, followed by yellowfin tuna, albacore tuna and then bluefin tuna. Japan depends on imports for most of its tuna supply. Imports as a proportion of total supply in Japan are $84.9 \%$ for bluefin tuna, $30.3 \%$ for albacore tuna, $79.0 \%$ for bigeye tuna and $76.8 \%$ for yellowfin tuna. The most expensive species is bluefin tuna, followed by bigeye tuna, yellowfin tuna and albacore tuna. Therefore, bluefin tuna is the highest-valued tuna and its share of the total tuna supply is small.

Table 1. Average monthly supply and price of each tuna species

\begin{tabular}{|c|c|c|c|c|c|c|c|c|c|}
\hline & \multicolumn{2}{|c|}{ Bluefin tuna } & \multicolumn{2}{|c|}{ Albacore tuna } & \multicolumn{2}{|c|}{ Bigeye tuna } & \multicolumn{2}{|c|}{ Yellowfin tuna } & \multirow{2}{*}{$\begin{array}{l}\text { Total } \\
\text { Supply } \\
\text { (ton) }\end{array}$} \\
\hline & $\begin{array}{l}\text { Supply } \\
\text { (ton) }\end{array}$ & $\begin{array}{l}\text { Price } \\
\text { (yen/kg) }\end{array}$ & $\begin{array}{l}\text { Supply } \\
\text { (ton) }\end{array}$ & $\begin{array}{l}\text { Price } \\
(\text { yen } / \mathrm{kg})\end{array}$ & $\begin{array}{l}\text { Supply } \\
\text { (ton) }\end{array}$ & $\begin{array}{l}\text { Price } \\
(\text { yen } / \mathrm{kg})\end{array}$ & $\begin{array}{l}\text { Supply } \\
\text { (ton) }\end{array}$ & $\begin{array}{l}\text { Price } \\
\text { (yen/kg) }\end{array}$ & \\
\hline \multicolumn{10}{|l|}{ Domestic } \\
\hline Fresh & 240 & 1533 & 2576 & 296 & 810 & 1031 & 682 & 662 & 4309 \\
\hline Frozen & 139 & 2046 & 1686 & 295 & 1646 & 742 & 1547 & 315 & 5017 \\
\hline \multicolumn{10}{|l|}{ Import } \\
\hline Fresh & 774 & 1956 & 39 & 649 & 1021 & 887 & 574 & 835 & 2408 \\
\hline Frozen & 1351 & 1850 & 1815 & 285 & 8222 & 647 & 6798 & 299 & 18186 \\
\hline \multirow[t]{2}{*}{ Domestic } & 379 & 1721 & 4262 & 296 & 2456 & 837 & 2229 & 421 & 9326 \\
\hline & $(15.1 \%)$ & & $(69.7 \%)$ & & $(21.0 \%)$ & & $(23.2 \%)$ & & $(31.2 \%)$ \\
\hline \multirow[t]{2}{*}{ Import } & 2125 & 1889 & 1854 & 292 & 9243 & 674 & 7372 & 341 & 20593 \\
\hline & $(84.9 \%)$ & & $(30.3 \%)$ & & $(79.0 \%)$ & & $(76.8 \%)$ & & $(68.8 \%)$ \\
\hline \multirow[t]{2}{*}{ Fresh } & 1014 & 1856 & 2615 & 301 & 1832 & 951 & 1256 & 741 & 6716 \\
\hline & $(40.5 \%)$ & & $(42.8 \%)$ & & $(15.7 \%)$ & & $(13.1 \%)$ & & $(22.4 \%)$ \\
\hline \multirow[t]{2}{*}{ Frozen } & 1490 & 1869 & 3501 & 290 & 9867 & 663 & 8345 & 302 & 23203 \\
\hline & $(59.5 \%)$ & & $(57.2 \%)$ & & $(84.3 \%)$ & & $(86.9 \%)$ & & $(77.6 \%)$ \\
\hline Total & 2504 & 1863 & 6115 & 295 & 11699 & 708 & 9601 & 359 & 29919 \\
\hline
\end{tabular}

An important issue is whether the regulation of bluefin tuna exports influences the price of other tuna species. If the export regulation not only raises the price of bluefin tuna, which accounts for a low share of the Japanese market, but also raises the price of bigeye tuna and yellowfin tuna, which account for high shares, then the regulation will have a much larger impact on the Japanese tuna market. Furthermore, an inventory control or supply plan that takes into account the change in the bluefin tuna supply will be required. The impact of a decrease in bluefin tuna supply on the prices of other species depends on the degree of substitutability between species. That is, if the substitutability between high-valued tuna and middle-valued or low-valued tuna is weak, export regulation of bluefin tuna will not raise the price of other tunas significantly. On the other hand, if it is strong, the regulation will raise the price of other tunas.

A number of empirical studies on price linkages between geographically separated markets have been conducted in terms of the informational efficiency between markets. When prices in different markets move proportionally 
to each other, there exists an arbitrage trade and markets are efficient. For example, Gardner and Brooks (1994), Baulch (1997), Meyer (2004), Asche, Jaffry and Hartmann (2007) and McConnell and Strand (2000) analyzed the prices linkage between geographically separated markets. Gardner and Brooks (1994) examined whether there exists a price relationship among geographically separated food markets in Russia using a cointegration test. Baulch (1997) tested the market integration of Philippine rice markets using a parity bound model (PBM). Meyer (2004) tested market integration in the European pig market using a threshold vector error correction model. Asche, Jaffry and Hartmann (2007) analyzed market integration and supply chain linkages for the European salmon market. McConnell and Strand (2000) tested the market linkage between Hawaii's and Japan's markets for bigeye tuna and yellowfin tuna. There are also some empirical studies analyzing the inter-species price relationship by using time series ana, including Gordon, Salvanes and Atkins (1993), Bose and McIlgorm (1996), Asche, Bremnes and Wessells (1999) and Jaffry, Pascoe, Taylor and Zabala (2000). Gordon, Salvanes and Atkins (1993) tested the existence of market linkages among high-valued (salmon), middle-valued (turbot) and low-valued (cod) fish species and found that the market for salmon is not linked to the markets for turbot or cod. Bose and Mcllgorm (1996) examined the inter-species price relationship in the Japanese tuna market for bigeye, yellowfin and albacore and found that the degree of substitutability between bigeye and albacore is substantially lower than the degree of substitutability between bigeye and yellowfin or between yellowfin and albacore. Asche, Bremnes and Wessells (1999) showed that the Law of One Price held for an international market with five salmon species. Jaffry, Pascoe, Taylor and Zabala (2000) examined the price interaction between salmon and the other main fish species in the Spanish market and concluded that salmon is, at best, the only substitute for tuna, hake and whiting, but found no significant interaction.

Some articles in these previous studies use vector autoregression (VAR) model or a vector error correction model (VECM). VAR and VECM are used to capture the interaction among multiple time series and simulate the impact of shock in one time series on other time series. For example, Apergis and Rezits (2003) simulated the price transmission effects among agricultural input prices, agricultural output prices and retail food prices by calculating the impulse response function based on a VECM.

The purpose of this study is to clarifie how the price of bluefin tuna and other species changes along with a decrease in import volume of Atlantic bluefin tuna. But most of the previous studies that analyze market linkages by time series analysis use time series price data and do not consider the effect of a change in supply on price. To accomplish this, we estimate the impact of a change in bluefin tuna supply on prices of four tuna species using a vector autoregressive distributed lag (VARDL) model, which incorporates the distributed lags of supply in present and past periods into the VAR model. Of course, fish characteristics that include fat content, fish size and method of landing also affect the price of tuna as McConnell and Strand (2000) mention. However, our focus is price level of whole market rather than price of an individual tuna. Therefore, we do not consider the effect of fish characteristics on tuna prices.

The structure of this paper is as follows. Section 2 introduces the data used in this study. Following that, Section 3 presents the model and empirical results. Section 4 simulates the impact of decrease in the bluefin tuna supply on the price of bluefin tuna and other species. Finally, Section 5 provides conclusions and notes remaining issues.

\section{Data}

In this study, we analyze the impact of a decrease in bluefin tuna supply on the price of four tuna species: bluefin tuna, albacore tuna, bigeye tuna and yellowfin tuna. For this purpose, we estimate a VARDL model which explains the price of each tuna type using past prices and supply in present and past periods. To estimate the model, we use data on prices and supply of each tuna species. We can obtain such data for domestic tuna from the Annual Report of Distribution Statistics on Fisheries Products and on imported tuna from Trade Statistics of Japan. In this study, we include southern bluefin tuna in bluefin tuna because the Annual Report of Distribution Statistics on Fisheries Products does not separate bluefin tuna and southern bluefin tuna. In order to simplify the model, we unify chilled and frozen tuna. Moreover, we do not distinguish between domestic and imported tuna for the same reason.

The methodology in this study includes the following steps. First, we test the stationarity of the price data because the VAR model requires that data series are stationary. Data series are stationary when they do not have a unit root. We can test for a unit root using an Augmented Dickey-Fuller (ADF) test. The second step varies, according to the results of the test for stationarity. When price series are stationary, we can estimate the VAR model. When price series are non-stationary, we should take the first difference of them and test for the unit root again. When the first differences are stationary (i.e. I (1)) we conduct a cointegration test developed by Johansen 
and Juselius (1990). When price series are cointegrated, we use VECM. Otherwise, we estimate the VAR model for the first differences. In the third step, we calculate the impulse response function and simulate the price transmission effects.

We conduct the ADF test with a month dummy because the prices of tunas vary according to the season. We estimate equation (1) and if $\tau=0$ cannot be rejected the data is stationary.

$$
\Delta p_{i t}=\alpha+\beta t+\tau p_{i t-1}+\theta_{1} \Delta p_{i t-1}+\theta_{2} \Delta p_{i t-2}+\cdots+\sum_{m=1}^{11} \gamma_{m} D_{m}+u_{i t}
$$

where $p_{\mathrm{i}}(i=1,2,3,4)$ indicates the price of the tuna species $\mathrm{i}, \mathrm{i}=1$ for bluefin tuna, $\mathrm{i}=2$ for albacore tuna, $\mathrm{i}=3$ for bigeye tuna and $\mathrm{i}=4$ for yellowfin tuna. $\mathrm{D}_{\mathrm{m}}(m=1, \ldots, 11) \mathrm{s}$ the month dummy variable. In conducting an ADF test, we determine the lag length and whether we include the constant term and trend. First, we chose the lag length in the ADF test using the Akaike's Information Criterion (AIC). Next, we test whether parameters of constant term and trend in the ADF test are significant. When parameters of constant terms or trends are not significant, we remove them and conduct an ADF test again. We show the results of the ADF test in Table 2. Table 2 shows that $\tau=0$ is rejected in the ADF test for all tuna prices at the $5 \%$ significance level. That is, all price series are stationary in their levels.

Table 2. Results of ADF test

\begin{tabular}{|c|c|c|c|c|c|c|c|}
\hline & Lag & $\alpha$ & & $\beta$ & & $\tau$ & \\
\hline Bluefin tuna & 2 & 421.52 & ** & - & & -0.18 & ** \\
\hline Albacore tuna & 6 & 35.86 & & - & & -0.17 & * \\
\hline Bigeye tuna & 11 & 308.50 & ${ }^{* *}$ & 1.19 & ${ }^{* *}$ & -0.52 & ** \\
\hline Yellowfin tuna & 3 & 64.54 & & - & & -0.43 & ** \\
\hline
\end{tabular}

Note. $*$ indicates statistical significance at the $5 \%$ and $* *$ at the $1 \%$ level.

In the case where the data has a trend there would be a bias in the estimator. Therefore, we should remove the trend from the variables. We remove trends by regressing the price and supply of each species on the time and month dummy $\mathrm{D}_{m}(m=1, \ldots, 11)$.

\section{Model and Empirical Results}

We can use the VAR model for estimation because there is no unit root in the price series. In order to consider the impact of a change in supply on price, we use the VARDL model which incorporates the distributed lags of supply into the VAR model (Note 1). The VARDL model is expressed in Equation (2):

$$
\mathrm{P}_{\mathrm{t}}=\mu+\sum_{\mathrm{k}=1}^{\mathrm{K}} \mathrm{A}_{\mathrm{k}} \mathrm{P}_{\mathrm{t}-\mathrm{k}}+\sum_{\mathrm{l}=1}^{\mathrm{L}} \mathrm{B}_{\mathrm{k}} \mathrm{X}_{\mathrm{t}-\mathrm{l}}+\sum_{\mathrm{m}=1}^{11} \eta_{\mathrm{m}} \mathrm{D}_{\mathrm{m}}+\varepsilon_{\mathrm{t}}
$$

where $\mathrm{P}_{t}\left(p_{1 t}, \cdots, p_{4 t}\right)$ is a $4 \times 1$ vector of prices, $\mathrm{X}_{t}\left(x_{1 t}, \cdots, x_{4 t}\right)$ is a $4 \times 1$ vector of supplies, $\mu\left(\mu_{1}, \cdots, \mu_{4}\right)$ is a $4 \times 1$ vector of constants. $\mathrm{D}_{j}(j=1, \cdots, 11)$ is a month dummy variable, $\eta_{i}\left(\eta_{1 i}, \eta_{4 i}\right)$ is a $4 \times 1$ vector of parameters and $\varepsilon_{t}\left(\varepsilon_{t}, \cdots, \varepsilon_{t}\right)$ is a $4 \times 1$ vector of error terms. $A_{k}$ and $B_{l}$ are $4 \times 4$ matrix of parameters. They are expressed as:

$$
A_{k}=\left(\begin{array}{ccc}
\alpha_{11 k} & \cdots & \alpha_{14 k} \\
\vdots & \ddots & \vdots \\
\alpha_{41 k} & \cdots & \alpha_{44 k}
\end{array}\right), B_{l}=\left(\begin{array}{ccc}
\beta_{11 l} & \cdots & \beta_{14 l} \\
\vdots & \ddots & \vdots \\
\beta_{41 l} & \cdots & \beta_{44 l}
\end{array}\right) .
$$

We choose the lag length of prices and supplies so as to minimize AIC. We show the AIC for each combination of lag lengths in Table 3 . We can see from Table 3 that a combination of two periods for price and zero periods for supply is the model which minimizes the AIC.

The estimation results of the VARDL model are reported in Table 4, which suggests the following. As estimates of $\alpha_{i i k}$ are significantly positive, a shock to the price of each tuna species in one period continues to have an effect on the own price over the long run. However, the estimates of $\alpha_{i j k}, i \neq j$ are positive at the $5 \%$ significant level with the exception of $\alpha_{431}$. That is, there is no inter-species price relationship except that the price of bigeye tuna has an effect on the price of yellowfin tuna. Furthermore, all estimates of $\beta_{i i}$ are significantly negative and no estimate of $\beta_{i j}, i \neq j$ is significant. This means that a decrease in the supply of one tuna species raises only the own price and does not have an effect on the price of other tuna species. 
Table 3. Lag length selection by AIC

\begin{tabular}{lllllll}
\hline \multicolumn{5}{c}{} & & \multicolumn{5}{c}{ Price } \\
\hline \multirow{4}{*}{ Supply } & 1 & 2 & 3 & 4 & 5 \\
& 0 & 4587.3 & 4564.3 & 4570.0 & 4574.2 & 4595.1 \\
& 1 & 4584.0 & 4564.8 & 4572.5 & 4578.3 & 4599.3 \\
& 2 & 4589.0 & 4574.0 & 4585.0 & 4591.8 & 4610.7 \\
& 3 & 4599.3 & 4581.1 & 4597.0 & 4602.2 & 4619.6 \\
\hline
\end{tabular}

Table 4. Empirical results

\begin{tabular}{|c|c|c|c|c|c|c|c|c|c|c|c|c|}
\hline \multirow[b]{2}{*}{ Param. } & \multicolumn{3}{|c|}{ Bluefin tuna } & \multicolumn{2}{|c|}{ Albacore } & & \multicolumn{2}{|c|}{ Bigeye tuna } & & \multicolumn{3}{|c|}{ Yellowfin tuna } \\
\hline & Coeff. & $t$-stat. & & Coeff. & $t$-stat. & & Coeff. & $t$-stat. & & Coeff. & $t$-stat. & \\
\hline$\mu$ & 1467.06 & $(2.61)$ & * & 120.37 & $(2.07)$ & & 336.71 & $(3.84)$ & & 124.13 & $(1.17)$ & \\
\hline$\alpha_{1,1}$ & 0.39 & $(4.05)$ & ${ }^{* *}$ & -0.01 & $(-0.62)$ & & 0.00 & $(-0.20)$ & & -0.02 & $(-1.17)$ & \\
\hline$\alpha_{1,2}$ & 0.34 & $(3.62)$ & ** & 0.01 & $(0.97)$ & & 0.00 & $(0.02)$ & & 0.00 & $(0.14)$ & \\
\hline$\alpha_{2,1}$ & -0.77 & $(-0.81)$ & & 0.45 & $(4.57)$ & $* *$ & -0.06 & $(-0.41)$ & & 0.12 & $(0.65)$ & \\
\hline$\alpha_{2,2}$ & 0.93 & $(0.98)$ & & 0.36 & $(3.65)$ & ${ }^{* *}$ & 0.07 & $(0.48)$ & & 0.04 & $(0.20)$ & \\
\hline$\alpha_{3,1}$ & 0.22 & $(0.30)$ & & -0.01 & $(-0.17)$ & & 0.89 & $(7.86)$ & $* *$ & 0.34 & $(2.44)$ & * \\
\hline$\alpha_{3,2}$ & -0.89 & $(-1.21)$ & & -0.02 & $(-0.26)$ & & -0.21 & $(-1.87)$ & & -0.20 & $(-1.44)$ & \\
\hline$\alpha_{4,1}$ & 0.11 & $(0.20)$ & & -0.08 & $(-1.29)$ & & -0.05 & $(-0.51)$ & & 0.13 & $(1.16)$ & \\
\hline$\alpha_{4,2}$ & -0.33 & $(-0.56)$ & & 0.01 & $(0.24)$ & & 0.08 & $(0.85)$ & & 0.37 & $(3.38)$ & ${ }^{* *}$ \\
\hline$\beta_{1}$ & -0.13 & $(-3.13)$ & ** & -0.01 & $(-1.54)$ & & 0.00 & $(-0.65)$ & & -0.01 & $(-0.95)$ & \\
\hline$\beta_{2}$ & 0.00 & $(-0.32)$ & & 0.00 & $(-4.49)$ & ** & 0.00 & $(-1.55)$ & & 0.00 & $(-1.39)$ & \\
\hline$\beta_{3}$ & 0.02 & $(1.53)$ & & 0.00 & $(-0.52)$ & & -0.01 & $(-2.64)$ & $* *$ & 0.00 & $(1.04)$ & \\
\hline$\beta_{4}$ & -0.01 & $(-0.71)$ & & 0.00 & $(0.02)$ & & 0.00 & $(-0.96)$ & & -0.01 & $(-4.10)$ & ${ }^{* *}$ \\
\hline
\end{tabular}

These results suggest that the market for bluefin tuna is not linked to the markets for other tuna species. However, there is a possibility that the market for yellowfin tuna is linked to the market for bigeye tuna. These results are consistent with Gordon, Salvanes and Atkins (1993), which indicated that the market for high-valued fish species was not linked to the market for middle-valued or low-valued fish species, and with Bose and Mcllgorm (1996), which indicated a possible substitutability between bigeye tuna and yellowfin tuna. From these results, we can predict that a decrease in imports of Atlantic bluefin tuna will raise the price of bluefin tuna but will not have an effect on the price of other tuna species.

\section{Impulse Response Function}

Based on the empirical results, we calculate the impulse response function to simulate the impact of a decrease in the supply of bluefin tuna on the prices of each tuna species (Note 2). However, we cannot observe the impact of a shock to supply on the price of each tuna species directly from the impulse response function because we treat the supply of bluefin tuna, which is the shock variable, as an exogenous variable. Thus, we consider the impact of a change in a unit of bluefin tuna supply on the prices of each tuna species as a $\beta_{i 1}$ unit shock of the error term $\varepsilon_{i}(i=1, \cdots, 4)$ at period 0 . Then, we can express it as Equation (3):

$$
\tilde{\mathrm{p}}_{i 1 t}=\sum_{j=1}^{4} \hat{\beta}_{j 1} \dot{p}_{i j t},
$$

where we denote $\dot{p}_{i j t}$ as the impulse response function and $\widehat{\beta}_{j 1}$ as estimates of $\beta_{j 1}$.

Once the restriction on exports of bluefin tuna is enforced, it will continue for several months or years. Therefore, we simulate the impact of decrease in the supply of bluefin tuna on the prices of each tuna species using a 
cumulative impulse response function. We express the cumulative impulse response function as $\dot{\mathrm{p}}_{i j t}=\sum_{\tau=0}^{t} \tilde{\mathrm{p}}_{i j \tau}$. As the average monthly supply of bluefin tuna in the Japanese market is 2,504 tons, approximately half of which is caught in the Atlantic Ocean, we simulate the price change when a decrease in the supply of bluefin tuna by 1,252 tons is maintained for 12 months. Figure 2 shows the simulation outcome. When the decrease in the supply of bluefin tuna by 1,252 tons is maintained for 12 months, the price of each tuna species rises by 550 yen per kilogram for bluefin tuna, 35 yen for albacore tuna and 15 yen for bigeye tuna and yellowfin tuna. These results suggest that bluefin tuna is regarded as luxury species in Japanese tuna market and degree of substitutability between bluefin tuna and other tuna species is low. Therefore, the prohibitions on imports and exports of Mediterranean and Atlantic bluefin tuna have little impact on the prices of other tuna species. On the other hand, the prohibitions will raise price of bluefin tuna significantly because the effect of it is not dispersed among other tuna species.

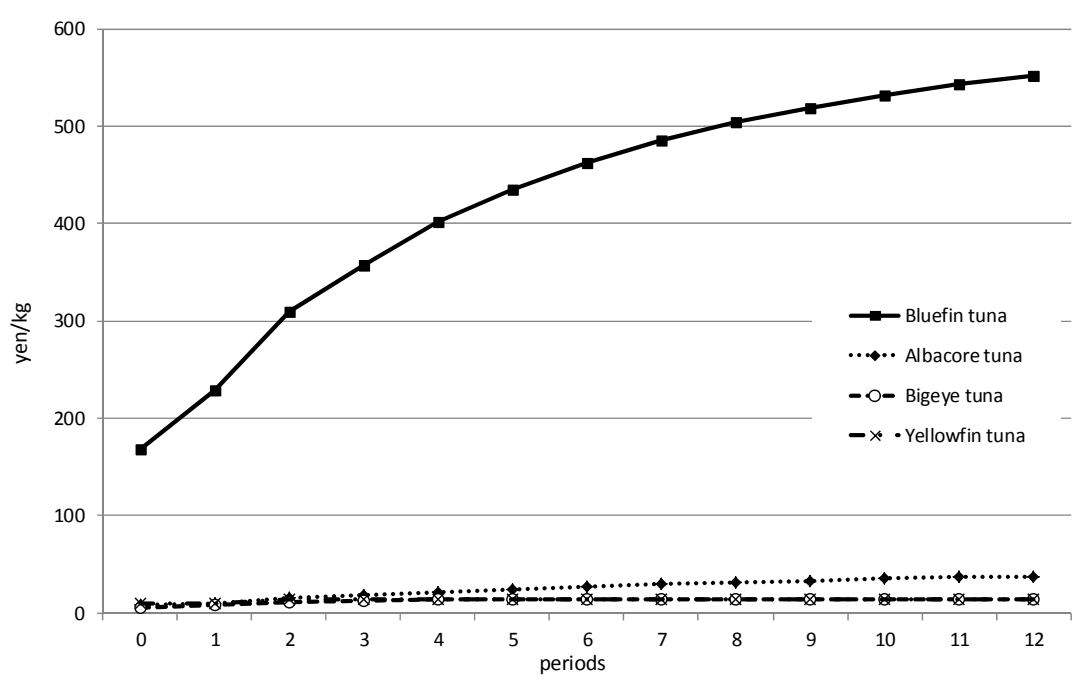

Figure 2. Response to bluefin tuna supply shock

\section{Conclusion}

In this study, we estimate the VARDL model for the prices of four tuna species, bluefin tuna, albacore tuna, bigeye tuna and yellowfin tuna, and simulated the effect of a decrease in the supply of bluefin tuna on the price of each tuna species. We obtained the following results from the simulation outcome.

There is a possibility that the market for yellowfin tuna is linked to the market for bigeye tuna. However, the market for bluefin tuna is not linked to any other market for other tuna species. Therefore, if the supply of bluefin tuna was halved for one year, its price would rise by about 550 yen per kilogram. However, the prices of other tuna species will not rise significantly. These results indicate that the prohibitions on import and export of Mediterranean and Atlantic bluefin tuna raise only the price of bluefin tuna but have little impact on the prices of other tuna species.

Finally, we note two important issues that require further investigation. First, in this study, we regarded tuna supplies as an exogenous variable. However, tuna catches or imports might be adjusted by a change in price and determined endogenously. Second, we did not distinguish chilled from frozen tuna and domestic from imported tuna in order to simplify the model. However, a model that takes these points into consideration would increase the number of estimated equations required and make it difficult to identify parameters. These two issues are to be considered in further research.

\section{Acknowledgments}

This work was supported by JSPS KAKENHI Grant Numbers 26450307.

\section{References}

Apergis, N., \& Rezits, A. (2003). Mean spillover effects in agricultural prices: The case of Greece. Agribusiness, 19(4), 425-437. http://dx.doi.org/10.1002/agr.10071 
Asche, F., Bremnes, H., \& Wessells, C. R. (1999). Product aggregation, market integration, and relationships between prices: An application to world salmon markets. American Journal of Agricultural Economics, 81(3), 568-581. http://dx.doi.org/10.2307/1244016

Asche, F., Jaffry, S., \&Hartmann, J. (2007). Price transmission and market integration: Vertical and horizontal

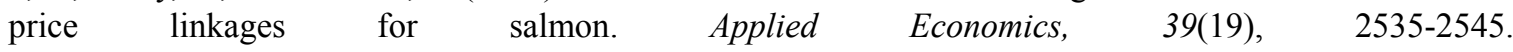
http://dx.doi.org/10.1080/00036840500486524

Baulch, B. (1997). Transfer costs, spatial arbitrage, and testing for food market integration. American Journal of Agricultural Economics, 79(2), 477-87. http://dx.doi.org/10.2307/1244145

Bose, S., \& McIlgorm, A. (1996). Substitutability among species in the Japanese tuna market: A cointegration analysis. Marine Resource Economics, 11, 143-155.

Boyd, D., Caporale, G. M., \& Smith, R. (2001). Real exchange rate effects on the balance of trade: Cointegration and the Marshall-Lerner condition. International Journal of Finance and Economics, 6(3), 187-200. http://dx.doi.org/10.1002/ijfe.157

Carroll, M. T., Anderson, J. L., \& Martínez-Garmendia, J. (2001). Pricing US North Atlantic bluefin tuna and implications for management. Agribusiness, 17(2), 243-254. http://dx.doi.org/10.1002/agr.1014

Gardner, B. L., \& Brooks, K. M. (1994). Food prices and market integration in Russia: 1992-93. American Journal of Agriculture Economics 76(3), 641-646. http://dx.doi.org/10.2307/1243681

Huang, H., \& Leung, P. (2011). Testing for market linkages between Hawaii and Japan's tuna markets. Fisheries Research, 109(2), 351-359. http://dx.doi.org/10.1016/j.fishres.2011.03.004

Gordon, D. V., Salvanes, K. G., \& Atkins, F. (1993). A fish is a fish is a fish? Testing for market linkages on the Paris fish market. Marine Resource Economics, 8(4), 331-343.

Jaffry, S., Pascoe, S., Taylor, G., \& Zabala, U. (2000). Price interactions between salmon and wild caught fish species on the Spanish market. Aquaculture Economics and Management, 4(3), 157-167. http://dx.doi.org/10.1080/13657300009380267

Johansen, S., \& Juselius, K. (1990). Maximum likelihood estimation and inference on cointegration-with applications to the demand for money. Oxford Bulletin of Economics and Statistics, 52(2), 169-210. http://dx.doi.org/10.1111/j.1468-0084.1990.mp52002003.x

McConnell, K. E., \& Strand, I. E. (2000). Hedonic prices for fish: tuna prices in Hawaii. American Journal of Agricultural Economics, 82(1), 133-144. http://dx.doi.org/10.1111/0002-9092.00011

Meyer, J. (2004). Measuring market integration in the presence of transaction costs-A threshold vector error $\begin{array}{lllll}\text { correction approach. } & \text { Agricultural 327-334. }\end{array}$ http://dx.doi.org/10.1111/j.1574-0862.2004.tb00269.x

Sims, C. A. (1980). Macroeconomics and reality. Econometrica, 48, 1-48. http://dx.doi.org/ 10.2307/1912017

\section{Notes}

Note 1. There are some empirical studies that use the VARDL model, for example, Boyd, Caporale and Smith, 2001

Note 2. Impulse response function developed by Sims (1980) is the method that presents a response to one standard deviation positive shocks

\section{Copyrights}

Copyright for this article is retained by the author(s), with first publication rights granted to the journal.

This is an open-access article distributed under the terms and conditions of the Creative Commons Attribution license (http://creativecommons.org/licenses/by/3.0/). 